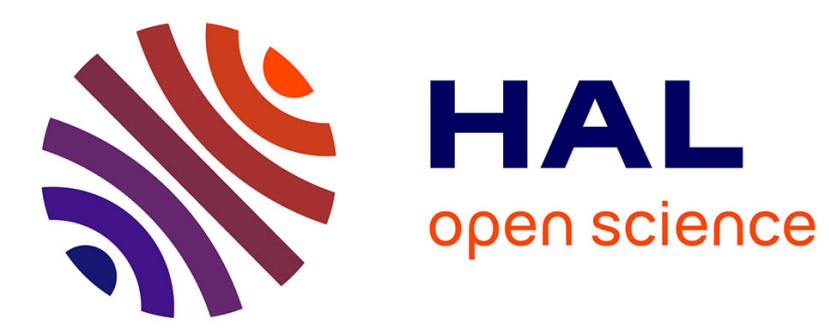

\title{
Resistance to Identity Categorization in France
}

Alain Blum

\section{To cite this version:}

Alain Blum. Resistance to Identity Categorization in France. Kertzer David, Arel Dominique. Census and identity: the politics of race, ethnicity, and language in national censuses., Cambridge University Press, pp.121-147, 2002, New Perspectives on anthropological and social demography. halshs00784139

\section{HAL Id: halshs-00784139 \\ https://shs.hal.science/halshs-00784139}

Submitted on 3 Feb 2013

HAL is a multi-disciplinary open access archive for the deposit and dissemination of scientific research documents, whether they are published or not. The documents may come from teaching and research institutions in France or abroad, or from public or private research centers.
L'archive ouverte pluridisciplinaire HAL, est destinée au dépôt et à la diffusion de documents scientifiques de niveau recherche, publiés ou non, émanant des établissements d'enseignement et de recherche français ou étrangers, des laboratoires publics ou privés. 
Blum Alain. 2002. Resistance to identity categorization in France.

\title{
Chapter Five
}

\section{Resistance to Identity Categorization in France}

\begin{abstract}
Alain Blum
For many years, public statistics in France, especially censuses, did not categorize the population on the basis of ethnicity. From the mid-1980s on, however, there has been a growing debate on immigration, leading to the progressive resurgence of the ethnicity question. The heated debate, challenging values so fundamental to French society, was fueled by the publication of a study on immigrant populations, pressure by various academic circles on the National Institute of Economic Statistics (INSEE in its French acronym) to change its method of counting immigrants, and by the preparation of the 1999 census. The debate poses some fundamental questions: Should we construct statistical categories based on ethnic affiliation to allow for the formulation of public policies directed against discriminatory practices? How do we define ethnic affiliation? How is demography to be used in the construction of such categories? What role should the census play in redefining the identity markers of individuals?

The debate is interesting in that it echoes the arguments voiced in France during the second half of the nineteenth century on the question of including categories in public statistics

178

In: Kertzer David, Arel Dominique (dir.), Census and identity : the politics of race, ethnicity, and language in national censuses. Cambridge, Cambridge University Press, p. 121-147. (New Perspectives on anthropological and social demography).
\end{abstract}


Blum Alain. 2002. Resistance to identity categorization in France.

based on origins, as well as the recurring debate on the statistical identification of immigrants.

Glancing at the debate, one might get the impression that it juxtaposes the adherents of a republican ethic versus those who defend an empirical reality, but, as we shall see, the relationship to the older debate is a complex one.

The debate is not only interesting, but important as well, as it raises the issue of the political implications of the analytic categories employed by social science, as well as the question of how these categories affect group formation within a given population. It is also exciting because it reveals numerous assumptions in the use of statistical categories and in the relationship between politics, social science, and political science. Moreover, it demonstrates that, in the relationship between research and politics, there are no straightforward political cleavages.

This chapter presents the major issues raised by the debate, and traces their references to the nineteenth century. It then provides an examination of its main arguments.

\section{The Issues of the Current Debate}

The debate on the introduction of ethnic categories into the statistical picture reappeared on the public scene indirectly, not during a discussion of the methods of identifying populations in the census, but during the immigration count. Pressure from the extreme right resulted in the circulation of numerous imaginary figures, a large degree of terminological confusion, and the questioning of certain works published by INSEE or INED (National Institute of Demographic Studies). Basically, the extreme right used the information on immigrants to demonstrate that the

\section{9}

In: Kertzer David, Arel Dominique (dir.), Census and identity : the politics of race, ethnicity, and language in national censuses. Cambridge, Cambridge University Press, p. 121-147. (New Perspectives on anthropological and social demography). 
Blum Alain. 2002. Resistance to identity categorization in France. segment of the population descended from North African immigrants would become preponderant in France one day. These projections were not only dangerous, they also completely disregarded the nationality law and mixed marriages. Scenarios were devised that fit the right's arguments on reproduction or immigration, and provided a springboard for attacking immigration of any kind through defending the idea of a "pure" French nation.

At the same time, the decision by the government to institute a commission of inquiry on immigration issues (the High Commission on Integration) necessitated precise statistics. ${ }^{1}$ The circulation of false figures and alarmist predictions not only generated great confusion, it also stigmatized the contribution of immigration and foreigners to the French population. It was in this context that the central institutions handling the statistical analysis of immigration sought greater precision in the categories of analysis. They did so by clearly distinguishing between the immigrant and the foreigner (Tribalat, 1989), studying immigration's contribution to the formation of the French population (Tribalat, 1991), and providing precise definitions of census categories, designed to help identify immigrant populations statistically.

And so the terms of the debate evolved. The initial interest in the flow of migration and its quantification gradually gave way to the question of what had become of the immigrants. Thus, the immigrants themselves became the focus of discussion, and there was already a willingness to include immigrant populations in a precise statistical framework. The questions were posed in strong normative terms, and therefore, implicitly, the debate on assimilation and integration echoes old discussions about differences in the behaviour of immigrants and the degree to which this

180

In: Kertzer David, Arel Dominique (dir.), Census and identity : the politics of race, ethnicity, and language in national censuses. Cambridge, Cambridge University Press, p. 121-147. (New Perspectives on anthropological and social demography). 
Blum Alain. 2002. Resistance to identity categorization in France.

behaviour was similar to or moving towards that of the (native) French. Demographic differences

(especially in connection with reproduction) and inter-marriages were used as indicators, more or less explicitly, in numerous studies (for example, INED, 1993; Munoz-Perez et al., 1984).

Once the focus had shifted to the immigrant population, the question arose as to how to measure it and how to differentiate within the category. The answer seemed to lie with finding the right descriptive marker and formulating ethnic categories for use in statistics. This phase of the debate coincided with the preparation of the 1999 French census and therefore stimulated discussions on the eventual introduction of new questions in surveys conducted after the census that would allow for analyses now felt to be necessary.

Thus, in the beginning, the debate did not refer directly to the categories employed in the census, nor to its history. Very soon, however, the incorporation of the discussion into a much larger debate promoted a rethinking of census categories and lent a historic dimension to the questions being posed.

In its initial phase, this new debate was limited to a confrontation between the public space and the world of research. On one side, institutions connected to research or statistics spent their time explaining the methodological framework of their work, the meaning of population projections, and the relationship between statistical and juridical categories. Certain elements within the media responded to these explications by pointing to the contradiction between the statistical view and a certain "common feeling" or intuition that was assumed to exist among immigrants or foreigners.

181

In: Kertzer David, Arel Dominique (dir.), Census and identity : the politics of race, ethnicity, and language in national censuses. Cambridge, Cambridge University Press, p. 121-147. (New Perspectives on anthropological and social demography). 
Blum Alain. 2002. Resistance to identity categorization in France.

These discussions took a new turn in 1995, when a violent polemic exploded within the research milieu itself, involving researchers from various institutions and statistical bodies, as well as the media and the political world. This debate was touched off by the publication of a major survey - the first of its kind in France - on the behaviour of immigrant populations (Tribalat, 1995). A brief overview of the debate demonstrates the close relationship between politics and statistical production and research, as well as the role of the public debate, which was filtered through the media.

First, it is worth pointing out the various aspects that made this debate important. The case constituted a clear example of the scientific elaboration of a concept and of its statistical measurement in social science. Numerous social actors participated more or less actively in the process. It is now clear that statistical measuring has a history, and that this history reflects the interaction between research, administration, and society as much as it reflects the internal intellectual debates of the disciplines producing the statistics (Desrosières, 1993; Alonso and Starr, 1987; Boltanski, 1982). Since the mid-1970s, the logic behind the construction and negotiation of social categories has been the object of various studies (In France, Desrosières and Thévenot, 1988; de la Gorce, 1991; in the United States, Anderson, 1988; in Great Britain, Szreter, 1996; on the Soviet Union, Blum, 1994; Houle, 1997)². Curiously, national categories received such attention only somewhat later, following the publication of works on nationalism (Anderson, 1991) or the brutal reappearance of the national question on the public scene. They

182

In: Kertzer David, Arel Dominique (dir.), Census and identity : the politics of race, ethnicity, and language in national censuses. Cambridge, Cambridge University Press, p. 121-147. (New Perspectives on anthropological and social demography). 
Blum Alain. 2002. Resistance to identity categorization in France.

are now the focus of a new history of multi-national empires (Blum et al. 1998; Blum and Gousseff

1997, Hirsch, 1997).

The shift in research focus towards the national question since the early 1980s, nourished by the political changes in Europe following the collapse of the Berlin Wall and of the USSR, thus transformed the debate on the nature of social categories and their construction into a discussion of the nature of national categories. The latter were understood in analogous fashion, i.e. as a process of construction and of negotiation between different levels of administration and politics, as well as representative groups of population, and as a process of interaction between different milieu: scientific and political in particular. In addition, a growing interest in the study of the colonial experience provided a field of inquiry and interdisciplinary encounter that went beyond the world of the statisticians or sociologists. This development initiated heightened interaction among the demographers, sociologists and political scientists, in the investigation of the construction of categories.

Another important aspect of the debate is the fact that the various organs producing statistics participated in it as much as the research institutes and the academics. There was thus a clear confrontation between those who elaborate the analytic categories, and provide advise on and help formulate public policy, and those providing the research on social dynamics. For a long time, social categories had been analyzed critically and mostly independent of the institutions that produced them—even if a statistician like Alain Desrosières, who pioneered this type of research, worked within the central statistical institution (Desrosières, 1993). The confrontation between

In: Kertzer David, Arel Dominique (dir.), Census and identity : the politics of race, ethnicity, and language in national censuses. Cambridge, Cambridge University Press, p. 121-147. (New Perspectives on anthropological and social demography). 
Blum Alain. 2002. Resistance to identity categorization in France.

these various spheres on the issue of constructing ethnic and national categories pushed the issue into the public debate. It is likely that the most important consequence of this will be the elaboration of new categories.

The debate also involves a confrontation between two traditions surrounding the use of statistics in social science: The "positivist" tradition views statistics as an object of reality, without questioning the nature of their source and the meaning of their categories. The "constructivist" makes the elaboration of categories and statistical methods the core of its enquiry. That being said, the opposition cannot be understood simply as a confrontation between two entirely distinct approaches, since the latter approach also attempts to be empirical. Nevertheless, these two directions in social science research suggest their own categories of enquiry and statistical analysis.

More generally, this debate leads to a larger discussion on the tools and measurements that can be employed to characterize the individual. Is the individual, at any point in time, a composite of certain fixed characteristics, or is he or she changeable by nature? Is the person the product of a particular life, of a certain path, or of history? Do individuals define themselves on their own, or more in relation to the world around them, and to what extent is their behaviour a product of their environment? As these questions suggest, the discussion raises questions about methods of analysis, i.e. the biography-based study versus the study of the environment in which individuals and groups live. The issue of how to measure diversity, which concerns the entire French population, is thus central, and raises questions about the role of statistics in general, as

184

In: Kertzer David, Arel Dominique (dir.), Census and identity : the politics of race, ethnicity, and language in national censuses. Cambridge, Cambridge University Press, p. 121-147. (New Perspectives on anthropological and social demography). 
Blum Alain. 2002. Resistance to identity categorization in France.

well as population studies and efforts to construct "tools" or instruments to help orient public policy at both the central and local levels.

Thus, an important aspect of the debate is that it grapples with the issue of the role of statistics in social science. For some, the formulation of public policies linked to particular social questions necessitates a statistical elaboration of these questions. If one wants to fight against discrimination based on "ethnic affiliation, one has to "identify in order to act" (Simon 1993b), and then to count. For others, it is crucial to bear in mind that statistics have symbolic value and that they not only reflect reality, but also construct it. Moreover, some believe that the conception of statistics as the ultimate tool in the formulation of public policy places too much power in the hands of the central government. The debate has therefore sparked a rethinking of the role of the census and, more generally, of statistical surveys of the public. What role do these enquiries play in the formulation and implementation of social policy? How are they useful?

Finally, the media, especially the press, have been a central participant in the debate, and so the academics engaged in the discussions have become a part of the general public debate.

The political nature of the debate reinforces this dimension since the discussions deal, in particular, with the political consequences of the use of certain concepts (ethnicity, nationalism) and categories (e.g. "immigrant”). It is suggested that demography, by its very nature, has direct uses in politics because of its tendency to focus on the question of origins (Le Bras 1998a) and, more generally, on reproduction and the biological aspect of the individual. This explains the link between certain demographic concepts and the ideology of the extreme right. This view further

185

In: Kertzer David, Arel Dominique (dir.), Census and identity : the politics of race, ethnicity, and language in national censuses. Cambridge, Cambridge University Press, p. 121-147. (New Perspectives on anthropological and social demography). 
Blum Alain. 2002. Resistance to identity categorization in France.

suggests that we cannot understand a certain discipline and its political impact without knowing its

history. In the same way, a statistical tool, and a measurement, cannot be properly understood apart from its origins - we have to know the context in which it was constructed. The same applies for institutions (Le Bras, 1994). In response to these views, others defend the measure itself, and maintain that its origins should have nothing to do with its interpretation or analysis.

\section{The Debate in Historical Perspective}

The debate on the use of ethnic categories in the census and the criteria employed to identify these categories is an old one in Europe. It first became important in the mid-nineteenth century, during the course of international statistics congresses, where, for the most part, European statisticians attempted to construct a single, formal framework for state-generated censuses and surveys in all territories.

Two sides emerged during these discussions, one represented by the Empires, the other by states such as France. On one side, Austria-Hungary and Russia considered ethnic (or national) identification to be primordial and an integral part of a tradition that statistics could help characterize with some precision and refine. The drawing up of ethnographic maps of these two empires was viewed as a progressive step that should be embraced by all. The only real question was how to construct a conceptual framework for censuses and ethnographic surveys which would allow for the fullest picture of the ethnographic characteristics of peoples, as they were then recognized in these empires. The opposing view, held by the French, which came to be embraced only after some years of hesitation in the first half of the nineteenth century, rejected any sort of

186

In: Kertzer David, Arel Dominique (dir.), Census and identity : the politics of race, ethnicity, and language in national censuses. Cambridge, Cambridge University Press, p. 121-147. (New Perspectives on anthropological and social demography). 
Blum Alain. 2002. Resistance to identity categorization in France.

identification of the kind promoted by the empires, especially in censuses. The definitive articulation of this position took place during the 1870s, and, since then, it has remained a constant in the debate. ${ }^{3}$

The public position generally advanced by the French did not question the existence of ethnographic differences, but argued that they applied only to certain states. They were therefore not of great interest. From the French perspective, differences between regions did not need to be reflected or recorded statistically. What was important was to defend the unity of the French nation. Representatives of other states, however, emphasized how the term "nationality" had one meaning in France and another in other countries. When the question of Bretons or the Basques was raised, Levasseur, one of the French representatives, talked about dialects, not about the existence or even the possibility of existence of Breton or Basque nationalities.

The basic question revolved around the criteria for identifying resident populations on the basis of those characteristics used to measure one of the major paradigms of nineteenth-century anthropology: race. Migrant populations did not figure in this particular discussion — the focus was on the characterization of the national population. Migration was of interest more in terms of the issue of movement across territories than in connection with ethnographic or racial questions. The polarization that developed in the debate is best understood in the following way: No distinction was made between countries of immigration and other European states, only between empires and nation-states. The ethnographic question was thus primarily a political question, connected to the political management or governing of the state. The cultural approach to the

In: Kertzer David, Arel Dominique (dir.), Census and identity : the politics of race, ethnicity, and language in national censuses. Cambridge, Cambridge University Press, p. 121-147. (New Perspectives on anthropological and social demography). 
Blum Alain. 2002. Resistance to identity categorization in France.

nation, as developed in Central Europe or in Russia, was not considered to be relevant by the

French, who favoured an approach centered on the citizen. Race became increasingly looked upon from a biological standpoint, but in a domain of public discourse having nothing to do with statistics or census categorizations.

\section{The Stability of French Censuses}

These old discussions led to the formulation of the basic framework of the census questionnaires, which was largely in place by the end of the nineteenth century. This framework, which is of great importance to our understanding of the current debate, took form, therefore, in a bi-polar context and is characterized, to this day, by a remarkable degree of inertia.

In this connection, the French position has been to distinguish ever more clearly between French citizens and foreigners. The former are viewed as constituting a single, unique nation. As for the foreigners, the approach has been to try to fit them into an increasingly clear, juridically precise, national category. For Noiriel $(1988,1991)$ or Brubaker (1992) the construction of these categories signifies the strengthening of the nation-state, which we see happening during the course of the nineteenth century. In their view, the censuses point to what Noiriel calls "the invention of the national.” The citizen and the foreigner became the two principal categories of analysis. Alongside these developments, the consolidation of the concept of the civic state, as well as the 1889 definition of citizenship, according to which nationality was based on jus solis, raised

In: Kertzer David, Arel Dominique (dir.), Census and identity : the politics of race, ethnicity, and language in national censuses. Cambridge, Cambridge University Press, p. 121-147. (New Perspectives on anthropological and social demography). 
Blum Alain. 2002. Resistance to identity categorization in France.

important questions that have remained with us since the end of the nineteenth century (Lacroix and Thave 1997; Gousseff 1997; Simon 1998).

Once the religion question was definitively rejected with the 1872 census, efforts centered on clarifying "national membership," particularly on the basis of the distinctions formulated for foreigners recorded in the census (Gousseff, 1997). In the first half of the nineteenth century, questions on nationality were either absent or very broad. ${ }^{4}$ The first census to include a question on nationality was that of 1851 . However, the lists of nationalities published at the time remained imprecise and combined juridical and political concepts.

The nationality question assumed full form by 1872, and has been modified very little since then. ${ }^{5}$ Central to the issue are two questions: place of birth and citizenship. The birthplace of persons born in France concerns the commune and the department of birth, and the colony (up until 1946) or country for those born outside of France. The main change to the question on nationality dates to 1891 and was the result of the 1889 law establishing jus solis. In 1891 and 1896, there were three possible responses to the question on nationality: "born to French parents”, “naturalized French”, or “foreigner, of which country”. In 1901, the responses were changed to: "born French” (or “of French birth”), “naturalized French” (or French through naturalization, through marriage, since 1946), and "foreigner, of which country" (since 1946, “of which nationality”). These questions have remained basically unchanged to our day, except for the introduction, in 1962, of a supplementary question on the original nationality of naturalized individuals.

189

In: Kertzer David, Arel Dominique (dir.), Census and identity : the politics of race, ethnicity, and language in national censuses. Cambridge, Cambridge University Press, p. 121-147. (New Perspectives on anthropological and social demography). 
Blum Alain. 2002. Resistance to identity categorization in France.

Thus, respondents are basically characterized as either French or foreigner, juridicallyspeaking, although "French through naturalization" is a category that does not entirely conform to this characterization. Country of origin is specified, but there is no ethnic dimension for the French. Such a dimension is also absent from the questions on migration, which sometimes ask (1968 and 1975) for the date of arrival of those respondents who came to France in between censuses. The major change in the 1999 census, to which we will return shortly, is the insertion of a question on the date of arrival of respondents born outside of France, regardless of when they came to the country (in 1968 and 1975, the question applied only to those who arrived in between censuses). Thus, to this day, immigration is treated like any migration, internal to the territory, and not like a separate variable, although the question is more precise at times. The changes introduced in 1999 do, however, point towards greater differentiation, i.e. towards a distinction between international and internal migration.

Thus, the nineteenth-century approach appears to be firmly established. Once resident in France, the immigrant is not subject to any differentiation on the basis of his origins. He is simply treated as an individual. From the beginning of the century down to the decades following World War II, the debate surrounding immigration often had ethnic overtones, as attempts were made to distinguish the "good" immigrant from the "bad," or to distinguish immigrants who could be assimilated from those who could not (Bertaux, 1997). Studies by Mauco (1932) and Sauvy (1954) have identified groups that are clearly ethnic in an effort to help formulate specific migration policies. This did not have an impact, however, on census categories, nor on large public surveys.

In: Kertzer David, Arel Dominique (dir.), Census and identity : the politics of race, ethnicity, and language in national censuses. Cambridge, Cambridge University Press, p. 121-147. (New Perspectives on anthropological and social demography). 
Blum Alain. 2002. Resistance to identity categorization in France.

We are looking at a tradition, therefore, which seeks, first and foremost, to affirm the identity of each respondent. This tradition is a solidly entrenched one, but never extended to the colonial empire, where the issue of citizenship for the indigenous population was faced with contradictory tensions. Thus the census used in the colonies was the only statistical enquiry that included an ethnic dimension.

\section{Colonial Ambiguity}

The coherence of the French approach to the census diminishes when we turn to the census used in the colonial territories (Blum et al, 1998), as was highlighted in 1878 by de Pietra Santa, during the First International Conference on Demography. The categories employed in the colonial census largely used distinctions that were considered ethnic elsewhere in Europe. Algeria is a good example (Kateb, 1998a and 1998b). The Algerian census tended increasingly towards the homogenization of the Muslim population into one ethno-religious group starkly differentiated from the "French" population, which itself was viewed as a single group into which other Europeans were gradually absorbed. During the 1830s, in the first few years after the colonization of Algeria, the military administration described the various populations it came into contact with in great detail, enumerating many different ethnic groups (Mzabits, Arabs, Kabyles, etc.). However, the progressive evolution of Algeria into an integral component of France, which did not grant citizenship to indigenous peoples, led to the simple distinction between Muslims and the European population.

191

In: Kertzer David, Arel Dominique (dir.), Census and identity : the politics of race, ethnicity, and language in national censuses. Cambridge, Cambridge University Press, p. 121-147. (New Perspectives on anthropological and social demography). 
Blum Alain. 2002. Resistance to identity categorization in France.

During the 1850s, the growing idea of an Algerian "race," representing a fusion of the various European populations inhabiting the colony, began to threaten the French government, which was fearful of secessionist movements. Thus, a 1865 decree provided all Europeans who had lived in Algeria for at least three years the possibility of becoming French, while the 1889 law on nationality extended jus solis to any European child born in Algeria. By contrast, a person indigenous to Algeria could become French only with enormous difficulty (Kateb, 1998b). In 1870, the Crémieux decree had granted French nationality to all Jews living in Algeria.

The census reflects these contradictions. Since the end of the nineteenth century, the Algerian census included three main categories: French, French as a result of the Crémieux decree, and indigenous. Kamel Kateb (1998a) observes:

In 1830, the colonizers found and described a population which it perceived as ethnically unusual, including Turks, Arabs, Kabyls, Mozabits, Koulouhglis, indigenous Jews, and Maurs. A century later, the indigenous population consisted only of Arabs, Kabyls, and Mozabits. And following the promulgation of the organic law on the status of Algeria in 1947, the French administration began to distinguish between Muslim and non-Muslim only. As paradoxical as it may seem, the Colonial administration promoted the Arabization of the once Berber-speaking population, as well as the spread of Muslim law, to the detriment of the customary law of the territory.

The census used in the Overseas Départements (Guadeloupe, Martinique, etc.) and Territoires (New Caledonia, Polynesia, etc.) resembles that devised for the colonies. ${ }^{6}$ Each

192

In: Kertzer David, Arel Dominique (dir.), Census and identity : the politics of race, ethnicity, and language in national censuses. Cambridge, Cambridge University Press, p. 121-147. (New Perspectives on anthropological and social demography). 
Blum Alain. 2002. Resistance to identity categorization in France.

territory is issued a separate questionnaire, not only because each one has a different administrative status, but mostly to accommodate political considerations and negotiations specific to each territory. Rallu (1998) has shown how the colonial conception of ethnic questions has produced various responses or approaches reflecting the interplay of diverse forces. In all of the départements abroad, the questionnaire used is the same as that for metropolitan France. However, the questionnaires issued to certain territoires gradually change from census to census in terms of how ethnicity and inter-breeding are measured. These changes are the result of political negotiations. In some cases, questions are introduced and later removed. In others, the census is interested only in the pure "races," and ignores the mixed population (Rallu, 1998). In two cases in Polynesia, in 1996, questions on ethnicity were dropped. In New Caledonia, the multiple declaration is simply not an option, although some have sought it, as also has been the case in Wallis and Futuna. Thus, the categories employed in these censuses are constantly changing, which makes for little continuity between one census and the next.

\section{A History of the Debate}

Let us now turn to the "technical" origins of the debate. In 1992, after a lengthy discussion and elaboration (which has yet to be studied), INED and INSEE conducted a survey entitled, “Geographic Mobility and Social Integration” (MGIS), dealing with the behaviour of immigrants and their offspring. The two institutions that produced the survey are both public institutions, involved in research, the gathering of statistics, and political activity. The former (INED), is a research center attached to both the Ministry of Social Affairs (now the Ministry of Employment

193

In: Kertzer David, Arel Dominique (dir.), Census and identity : the politics of race, ethnicity, and language in national censuses. Cambridge, Cambridge University Press, p. 121-147. (New Perspectives on anthropological and social demography). 
Blum Alain. 2002. Resistance to identity categorization in France.

and Solidarity) and the Ministry of Research. INSEE, which is the central statistical institution

(Direction de la statistique), comes under the Ministry of the Economy and Finance. Its major tasks include the census, vital registration statistics, and large public surveys, such as those on employment, the family, health and housing.

The survey was first presented to the public in 1993 (Simon 1993a) and the first results were published in 1995 (Tribalat, 1995a) in Faire France, a publication with a large audience. Another trigger to the debate, and especially to the interaction between the survey and the census question, was the criticism leveled against INSEE by certain academic authorities, suggesting that the census could measure neither the forms, nor the effects of immigration (Dupâquier 1997; INSEE 1998).

The main idea behind the MGIS survey was to break with the traditional distinction between foreigners and French citizens employed in French censuses. Instead, new criteria were used which took into account the very process of migration and length of stay in France, and which distinguished between citizens whose parents were born in France and those whose parents were immigrants. The aim was to produce a study of immigration and its future, of immigrants and their descendants, and not of the nationality of the population.

Neither the planning nor the conducting of the survey prompted any particular discussion. An acrimonious debate did, however, ensue with the publication of its first results, the statistical categories used, and the more general way in which the results were presented. In the introduction

194

In: Kertzer David, Arel Dominique (dir.), Census and identity : the politics of race, ethnicity, and language in national censuses. Cambridge, Cambridge University Press, p. 121-147. (New Perspectives on anthropological and social demography). 
Blum Alain. 2002. Resistance to identity categorization in France.

to the first work to appear on the survey, the author noted that the survey allowed for a departure from the "republican" tradition that ignored ethnic differences and was peculiar to France:

In France, the departure from the distinction foreigner/French is a difficult move for purely ideological reasons: To distinguish the French on the basis of their national or ethnic origins is simply ignominious, a defamation, as it opens the door to discrimination (Tribalat, 1995).

The author's position is thus explicitly in opposition to a "republican conception of statistics," although, as we shall see, the debate is not a continuation of the old discussions outlined above. Different concepts were used in each debate. However, references to the past and to the history of statistics gathering do inform certain arguments belonging to this position. It is true that the French census tradition is peculiar, given the absence of ethnic criteria, which are employed in many different ways in numerous countries. According to the author, this peculiarity is attributable to an "ideological" refusal, in continuation of nineteenth-century stances. The approach of the MGIS survey represents a new way of characterizing individuals, a more objective way which reflects a reality that can no longer be denied. A rupture is what we are dealing with, and no less, as is demonstrated by the strong opposition of numerous institutions, for instance INSEE, which collaborated on the survey, but then, according Michèle Tribalat, tried to censor it (Tribalat, 1995b). This survey thus provided a way of resisting the "politically correct" attitude that has dominated social science and statistics gathering to this day. It rejected the artificial idealization and homogenization of the population of France in favour of the observation of social reality.

195

In: Kertzer David, Arel Dominique (dir.), Census and identity : the politics of race, ethnicity, and language in national censuses. Cambridge, Cambridge University Press, p. 121-147. (New Perspectives on anthropological and social demography). 
Blum Alain. 2002. Resistance to identity categorization in France.

Thus, while the survey was formulated and conducted in order to study the behaviour of immigrants, it became a means towards the preliminary exploration of ethnic diversity once published. It therefore broadened the debate by raising the larger issue of whether and how to deal statistically with ethnic diversity. Given its position, INSEE was necessarily implicated in the debate, the question being what role it should play in this line of research, which would eventually require new census questions.

The broadening of the debate was not only self-generated, but also the result of a growing sensitivity in the political world and among the media to issues having to do with urban violence, the exclusion of certain groups from schools, and discrimination in the workplace and in housing. Previously, these issues had been addressed discreetly and on the basis of geographic dictates, as was done by the Ministry of National Education when it established the Priority Educational Zones, followed by the Sensitive Zones, which were defined geographically, not ethnically. As the debate grew in scope, however, these issues affecting French society were suddenly perceived as conduits to understanding the nature of ethnic tensions and exclusion.

Once the study was presented to the public, the debate evolved in various settings and assumed various forms, attesting to the diversity of participation in a discussion that cut through several public spaces: research, statistical institutions, political institutions, and the media. The press devoted much attention to the first publication based on the survey, focussing on its demonstration of immigrant integration and of a lesser degree of segregation than had been assumed to exist to date. A first set of articles soon appeared in a journal symposium (Revue

196

In: Kertzer David, Arel Dominique (dir.), Census and identity : the politics of race, ethnicity, and language in national censuses. Cambridge, Cambridge University Press, p. 121-147. (New Perspectives on anthropological and social demography). 
Blum Alain. 2002. Resistance to identity categorization in France.

française des affaires sociales, 1997), raising the question, in rather contradictory fashion, of "the categories pertaining to foreigners of foreign origin.” The concepts of integration (Decouflé, 1997), assimilation (Bertaux, 1997), and of census categories used to count foreigners (Gousseff, 1997; Lacroix and Thave, 1997) were the focus of these first articles. I cautioned against an analysis of immigrants that locked them into a narrow category, as opposed to a demographic approach lending itself to a more complex understanding of the individual. The latter approach takes account of the individual's experience or history, and eschews the idea of a fixed, or unchanging identity (Blum, 1998).

The debate thus spread in different directions. It grew further with the publication of a work that was very critical of the survey (Le Bras, 1998a and 1998b) and, especially, of the relationship between social science research and political stances based on the categories employed in the survey. ${ }^{7}$ Some time later, during a day-long session entitled "Statistics without Conscience Spells Ruin...,” the labour unions of INSEE cautioned against the use of ethnic categories in the census. The session's title aptly conveys the complexity of the issues emerging from the growing debate, which now clearly extended to the census question and the possible consequences of an ethnically-based analysis of public statistics.

At the start, there were five main criticisms leveled against the ethnic approach that was presented in Faire France (especially in: Bertaux, 1997; Blum, 1998; Rallu, 1998; Héran 1998; and Richard, 1999b). I will summarize these, before discussing the responses to these criticisms.

197

In: Kertzer David, Arel Dominique (dir.), Census and identity : the politics of race, ethnicity, and language in national censuses. Cambridge, Cambridge University Press, p. 121-147. (New Perspectives on anthropological and social demography). 
Blum Alain. 2002. Resistance to identity categorization in France.

The first criticism centered on the expression "Français de souche" (French by root, or indigenous French), which is used to describe persons born in France to parents also born in France. The commonly used expression came into question for several reasons. There was concern about how the term, heretofore used mostly by the extreme right, might be used politically if it were endowed with a scientific legitimacy. The very origins of the term as a racial description also came under scrutiny, as did the possibility of defining the population, given mixed marriages and other connected processes of differentiation. Finally, a contradiction was noted in the term itself, which links a juridical concept to a natural one. If one is "French", this means one is of the French nationality as understood by the courts; “de souche” refers to a biological fact. Indeed, we have seen that, since the nineteenth-century, the conception of "French" became a juridical one, and not a socio-cultural one; or, more precisely, the socio-cultural conception was reduced to the juridical one.

The second criticism revolved around the way that the ethnic category had been devised and defined. Several authors pointed out that it was defined differently for different groups, depending on the origins of the respondents. Nationalities (in the sense of citizens from another country) were used for those respondents born in Europe (thus French, Spanish, Portuguese, but not Catalan, Basque, or Breton), and only a small number of ethnic, or non-national categories were employed to describe members of the North African and Turkish populations (Berbers, Arabs, Kurds). The Sub-Saharan Africans fell into several categories (Fulani, Mands). According to the critics, such use of the ethnic category stemmed from colonial practice. Finally, the use of a

In: Kertzer David, Arel Dominique (dir.), Census and identity : the politics of race, ethnicity, and language in national censuses. Cambridge, Cambridge University Press, p. 121-147. (New Perspectives on anthropological and social demography). 
Blum Alain. 2002. Resistance to identity categorization in France.

mother tongue as a criterion in the construction of these categories was called into question. On a more general level, the criticism regarding ethnic categories expressed a concern about subjecting weak perceptions of group affiliation to statistical analysis. Echoing views expressed in nineteenthcentury works on racial anthropology, this latter argument cautioned against rushing to analyze something that was only just coming into being and, by so doing, making it a reality (Blum 1998; Todd 1994, for his earlier reflections on the subject).

A third area of disagreement centered on the contradiction between the willingness to analyze the process of migration on the one hand, and, on the other, the use of ethnic categories which focussed the study on the origins of the respondent, rather than his or her biography, or experiences. The issue was not whether there should be questions on place of birth, parents' place of birth (or parents' original nationality), or mother tongue. Such questions had already appeared in numerous surveys going back many years, including those conducted by INSEE (Héran, 1998). The point had to do with making these questions the center of the analysis and, in particular, with their "conceptualization" as ethnic categories. This shift has fundamental implications. Ethnicity cannot be defined by a criterion like origin, whether it is defined by place of birth or ascendancy, since it results from a combination of multiple criteria, having equally to do with origin, place of residence, social networks, migratory path etc.

The debate was transformed into a polemic that grew more public and more passionate in connection with the fourth body of criticism. The issue here had to do with the political use of such analyses, and led some to denounce the link between certain demographers and the political milieu

199

In: Kertzer David, Arel Dominique (dir.), Census and identity : the politics of race, ethnicity, and language in national censuses. Cambridge, Cambridge University Press, p. 121-147. (New Perspectives on anthropological and social demography). 
Blum Alain. 2002. Resistance to identity categorization in France.

of the extreme right. Social science's interest in the concrete conditions behind the transmission of concepts and ideas led to an exploration of the political uses of demography (Le Bras 1998a; Richard 1999). This produced an analysis of the various networks of people who bridged demography as a scientific discipline and demography for political use. The study was based on an examination of traditional French political circles, for whom birth and reproduction are pivotal issues (Le Bras 1981 and 1991). In this milieu, population growth through reproduction is encouraged, while immigration is often forgotten, or rejected. It was this type of analysis that led to legal action, as was indicated earlier. INED, which launched the suit, felt that its credibility had been called into question because of an alleged proximity to the extreme right, although this charge was never stated outright by the author.

Finally, criticism also revolved around the census and the population registers in connection with the issue of privacy and how the information gathered by these means would eventually be used. French society today is very uncomfortable with the creation of files on individuals. This wariness is attributable, in part, to the power wielded by CNIL (Commission on Computerization and Freedom), which is responsible for handling such files, and also because of disturbing historical recollections triggered by the discovery of a file on French Jews, compiled by the Vichy régime during the Second World War. This file, and its relation to the census and the SNS (National Statistical Service), was under study during the course of the debate, and had just been the object of an official government report (Rémond 1996), following a lengthy polemic revolving largely around the question of its preservation. It is not surprising that INSEE unions'

In: Kertzer David, Arel Dominique (dir.), Census and identity : the politics of race, ethnicity, and language in national censuses. Cambridge, Cambridge University Press, p. 121-147. (New Perspectives on anthropological and social demography). 
Blum Alain. 2002. Resistance to identity categorization in France.

one-day session on ethnic statistics also dealt not only with the issue of the use of ethnic categories in present-day public statistics, but also with the work of SNS and the census in connection with French Jews in World War II.

\section{Response to Criticisms}

The responses to the criticisms outlined above were based, generally speaking, on an argument which had little to do with the initial publications on the survey, but which has since become dominant in the debate: the need to fight discrimination based on people's origins, and to devise methods of instituting real policies against such practices. For several years, there has been a growing awareness of and reflection on the discrimination problem and other social issues, including urban violence, access to employment, and the management of social policy. The institutional need for better information on immigrants, supported by the High Council on Integration, has often given support to demands for a better knowledge of immigrant populations according to their origins. The basic issues raised on this side of the debate (Simon 1998) had to do with the difficulties that immigrants encountered in their search for employment and housing, as well as with the criteria that police used in identity checks, which are often based on physical appearance, family name, etc.

The debate on discrimination, which has grown to unprecedented levels in the past ten years, is not only about immigrants and issues relating to immigration. It is also about discrimination between the sexes, especially in politics, generating a discussion of quotas versus other, voluntary methods of prompting real equality. However, these two threads of the same

In: Kertzer David, Arel Dominique (dir.), Census and identity : the politics of race, ethnicity, and language in national censuses. Cambridge, Cambridge University Press, p. 121-147. (New Perspectives on anthropological and social demography). 
Blum Alain. 2002. Resistance to identity categorization in France.

debate have barely intersected. They are handled differently and deal with issues that hardly concern them both: Access to employment and housing, academic performance, and urban violence as a consequence of discrimination are issues important to the discussion on the introduction of ethnic categories in public statistics, while the debate on gender equality focuses on the question of access to politics.

Another argument on this side of the debate is that there is a need for the use of explicit tools to help in the formulation of policies. Proponents argue policies are often introduced which take ethnicity into account surreptitiously, but do not explicitly admit to doing so, or explain how. A clearer picture of the ethnic situation would help produce policies that were open and comprehensible without reference to complicated, convoluted explanations, which have a tendency to deform reality and can be dangerous to boot.

Another line of response to the criticisms discussed above is a formal denial of any link to the extreme right. The emphasis placed by some of the participants in the debate on the relationship between certain circles in the demographic world and the Front National, or on the question of how demography could easily be used to justify some extremist arguments, was seen by certain researchers as an attack on them personally, or on their institution, even though they were far removed from extremist politics.

This latter response is connected to the difficult issue of the political uses of statistical categories and the responsibility of the institution or researcher involved in the future use and possible implications of these categories, especially in the hands of the extreme right. For some,

202

In: Kertzer David, Arel Dominique (dir.), Census and identity : the politics of race, ethnicity, and language in national censuses. Cambridge, Cambridge University Press, p. 121-147. (New Perspectives on anthropological and social demography). 
Blum Alain. 2002. Resistance to identity categorization in France.

there is a responsibility, but others are more concerned with what they perceive as an unjustified and slanderous questioning of the motives behind research conducted in connection with, or under the auspices of formal, established relationships. A good example is that of INED and how it originated. The institution, originally called the Alexis Carrel Foundation, was established by Vichy, and its founder was known for his extremist and eugenist positions. The researchers currently affiliated with INED have nothing to do with its dubious beginnings. Why, then, should INED's origins be used in arguing about the dangers presented by certain works emanating from this institution?

Finally, the experience of other countries with regard to the use of ethnic statistics is cited as a positive argument just as often. Examples from the Anglo-Saxon world figure prominently in this discussion, and are used to demonstrate the absence of any particular political stance in connection with the use of ethnic statistics (Simon 1997). The peculiar French practice is thus denounced as a means by which a strong ethnic reality is left hidden. According to this argument, the use of racial and ethnic categories in the British, American, and Canadian censuses legitimates the statistical enquiry into ethnicity.

\section{Ambiguities}

Let us now turn to an examination of the various levels and ambiguities in the debate. The development of an open debate on the internet, through a discussion group, has promoted

In: Kertzer David, Arel Dominique (dir.), Census and identity : the politics of race, ethnicity, and language in national censuses. Cambridge, Cambridge University Press, p. 121-147. (New Perspectives on anthropological and social demography). 
Blum Alain. 2002. Resistance to identity categorization in France.

broader participation and offered new emphases, which helps us to distinguish between different levels of arguments. ${ }^{8}$

We must first distinguish between what might be considered as falling within the scope of public statistics and that which has more to do with specific research, conducted by research teams. The statistics, or large surveys conducted by public institutions which largely monopolize the study of these questions, quickly become points of references, contradicted by no one.

One of the reasons for the confusion in the discussions has to do with the fact that research and public statistics do not share the same imperatives. It seems clear that a general census of the population should in no way include measures and personal files relating to "linguistic," or "religious" groups, or to categories such as "French with at least two French grand-parents” etc. . . . since these kinds of categories take hold in the collective imagination (sometimes strengthening the ideological categories present in public opinion). More importantly, public statistics, particularly the census, constitute an official database compiled by means of obligatory response to an official agent. (Tripier 1998). Another important aspect to consider in examining the debate relates to the evolution of social science thinking in our time, including important changes in the characterization of the individual. In an earlier article (Blum 1998), I observed how the naturalism [primordialism] expressed in these two works (Tribalat 1995 and Todd 1994) . . . is striking in more than one way. This attitude, which gained in importance during the second half of the nineteenth century, slowly but surely took hold of

In: Kertzer David, Arel Dominique (dir.), Census and identity : the politics of race, ethnicity, and language in national censuses. Cambridge, Cambridge University Press, p. 121-147. (New Perspectives on anthropological and social demography). 
Blum Alain. 2002. Resistance to identity categorization in France. researchers, leading to an approach that ignored the individual, as well as his daily activities and life experiences. Moreover, this line of thinking did not recognize the importance of multiple paths in the individual's behaviour. Its statistical component rested on the construction of sharply defined categories that were supposed to a be a faithful reflection of reality ...

One current that is apparent in social science and history today distances itself from this kind of determinism [Lepetit 1995]. A new approach is being constructed, which attributes a much greater complexity to the individual, taking into account experiences and interactions that can no longer be understood solely in terms of the opposition, or the relationship between large groups or classes [ . . ]

It is obvious that the biographical dimension of migration necessitates a research approach that goes beyond place of birth and mother tongue in attempting to understand the individual. These markers are part of an individual's make-up, but they interact with other, dynamic factors. It would be impossible to take this complexity into account were one to introduce a definition of ethnicity based only on these markers.

The question arises, therefore, as to whether there exist in demography concepts which favour the latter approach. Several works suggest that there are. The calling into question of the traditional tools of demography by numerous researchers interested in approaches which take into consideration the individual's experiences further suggests that profound changes that break with past methods are not only possible, but probable (Courgeau; Lelièvre 1996).

205

In: Kertzer David, Arel Dominique (dir.), Census and identity : the politics of race, ethnicity, and language in national censuses. Cambridge, Cambridge University Press, p. 121-147. (New Perspectives on anthropological and social demography). 
Blum Alain. 2002. Resistance to identity categorization in France.

Furthermore, even if it is well known and accepted that an individual's self-perception is closely connected to the conditions prevailing at any given moment in time, to the context in which the question is asked, and to the individual's position when questioned, asking people to define themselves is still a worthwhile exercise. The complexity of identity warrants great caution. It is taking caution quite far, however, when one seeks to define identity externally, without asking people what they think. There is thus a significant difference between the Anglo-Saxon approach, where each person states what he or she thinks he or she is, or would like to be, and the positivist approach, which considers ethnic identity to be an external characteristic. Implicit here is the difference between "ethnic categories" and "ethnic characteristics.” By constructing statistical categories on the basis of a few simple variables, the researcher creates static categories independent of, or separate from actual cultural experience.

On a more general level, the central issue is how best to measure diversity in social science:

No less important is the question of which theoretical and methodological tools are the most effective for grasping and describing the complexity and richness of a society in motion. It is at this general level that the basic questions arise since, if there is one thing that is understood in social sciences - and has been for the past few years - it is that the essence of the historical process lies in diversification. Historians and sociologists, anthropologists and economists all know that society is changing constantly. At every moment, it is being transformed by the incessant activity of all of its members. At every

In: Kertzer David, Arel Dominique (dir.), Census and identity : the politics of race, ethnicity, and language in national censuses. Cambridge, Cambridge University Press, p. 121-147. (New Perspectives on anthropological and social demography). 
Blum Alain. 2002. Resistance to identity categorization in France.

moment, France is profoundly different from what it had been in the past and from what it will be in the future for no other reason than because each person is constantly confronted by new situations which compel him to adjust his perceptions, his beliefs, his views, and . . . his memories [. . .] The challenge facing research is thus to find a way of grasping diversity and complexity in motion. Every person has a past. I would even say that every person can imagine himself in numerous pasts and with numerous roots, as sociologists and anthropologists know very well. The interesting thing, therefore, is to understand how these multiple origins and memories, and the constant adjustment of perceptions operate and manifest themselves over time. In present terms, understanding difference means understanding the dynamics of a society (Gribaudi 1998)

Finally, one has to consider the political dimension of these issues. We already looked at this angle in terms of the political debate. Here, I would like to discuss the relationship between a political, institutional system and the analytical categories used. An ethnic category is also meaningful, in term of a socio-political actor, if it plays a role as such, in the socio-political relations characterizing the life of a given society. When a community is represented as it is, or behaves as a lobby, it is a real entity, and acts as an intermediary between the various social and institutional levels, or components present in society. By contrast, when a community does not play a role on its own, a researcher should not seek to invent it.

207

In: Kertzer David, Arel Dominique (dir.), Census and identity : the politics of race, ethnicity, and language in national censuses. Cambridge, Cambridge University Press, p. 121-147. (New Perspectives on anthropological and social demography). 
Blum Alain. 2002. Resistance to identity categorization in France.

The first level of analysis is the social, followed by statistical observation and the reification of the analytical categories. The question arises: is statistical observation a necessary and effective tool in the fight against segregation and discrimination?

The complexity of the discussion is connected to the fact that there are three levels to the debate, each interacting with the other: the political, sociological, and statistical. In addition, there is often confusion among these levels. The political dimension has to do with the relationship between the individual and the political institution, which is tied to the particular political models of given states, as they have evolved over time. The sociological dimension of the debate revolves around the issue of ethnicity in France, whether ethnic reasoning or thinking is present, and to what extent ethnicity plays a role in interactions between individuals at the professional and social levels. The question thus is: can we study and actually observe an eventual ethnicization of French society? This question is inherently a sociological one. There are a few works that deal with it, in the context of more micro-social than macro-statistical studies, and these demonstrate the complexity of any eventual ethnic-based thinking (Simon 1998; Simon and Tapia 1998). The central question in the debate examined here is more about whether we can study behaviors related to ethnic configurations, or discrimination based on ethnic criteria, through an approach that combines research among immigrants on the one hand, and statistics generated through censuses, or large public surveys, on the other. The statistical approach constructs and reifies without necessarily grasping complex and changing realities.

In: Kertzer David, Arel Dominique (dir.), Census and identity : the politics of race, ethnicity, and language in national censuses. Cambridge, Cambridge University Press, p. 121-147. (New Perspectives on anthropological and social demography). 
Blum Alain. 2002. Resistance to identity categorization in France.

It is worth noting the predominance of immigration and related issues in the debate on the use of ethnic categories. The question arises not about refining the description of the French population, on the basis of cultural diversity observed in regions, or of networks of people defining themselves on the basis of some regional origin, but only about refining the description of immigrant population. This makes it difficult to draw in other pertinent discussions, despite numerous references to the American, Canadian, and British experiences, since in these countries ethnicity is largely disassociated from the question of migration. It also accounts for the centrality of integration and assimilation to the debate, both of which are constantly linked to ethnicity, while multiculturalism receives relatively little attention. This explains the fact that almost all of the participants in the debate invoke the republican model, regardless of their position.

\section{The Construction of Reality}

It is still too early to say what effect the debate will have on statistical practice in France and on the perception of which characteristics are most effective, or appropriate for describing a given population. There is no doubt, however, that the introduction of ethnic statistics, which is being discussed largely in public institutions, remains a possibility. A recent report on discrimination observed: "We must first measure discrimination, before we can combat it. This means that we must revise our statistical tools in such a way as to take into account ethnic or national characteristics, while, at the same time, taking precautions against possible ill uses

of the data" (Bernard 1999). ${ }^{9}$ The debate, however, has been conducted in an atmosphere of

In: Kertzer David, Arel Dominique (dir.), Census and identity : the politics of race, ethnicity, and language in national censuses. Cambridge, Cambridge University Press, p. 121-147. (New Perspectives on anthropological and social demography). 
Blum Alain. 2002. Resistance to identity categorization in France.

growing suspicion regarding the creation of various files containing precise markers identifying individuals or groups. It is worth observing that the same arguments are found in the United States, as in the decision of some states (California, Washington and Texas) "to ban the collection of racial demographic information and data on ethnic inequality” (Jenkins 1999).

It is also apparent that hazy and poorly constructed concepts have made steady inroads into various discussions. Thus, a historical magazine aimed especially at teachers included a “dictionary of terms connected to immigration,” which provided precise definitions for such terms as, "Français de souche” (indigenous French), "integration," and "assimilation.” The same magazine reproduced figures on polygamy which were based on a statistical error (Le Bras, 1998a), without employing or issuing any caution. It shows how large public surveys conducted by public institutions can be accepted uncritically by the media. If new terms or concepts are introduced in such a survey, they quickly begin to be considered as "scientific" and to be widely used.

Is this to say that such a statistical approach was needed before public policies based on ethnic distinctions could be implemented? And is it not unrealistic to claim that, without this kind of statistical approach, ethnic categories would not take shape? There is certainly no straightforward answer to these questions.

Two examples from public policy can help throw some light on these issues. The first has to do with a violence prevention policy, implemented by a Parisian public transport organization (RATP), which oversees urban transportation in the Paris area. Michel Wieviorka (1999) offered

In: Kertzer David, Arel Dominique (dir.), Census and identity : the politics of race, ethnicity, and language in national censuses. Cambridge, Cambridge University Press, p. 121-147. (New Perspectives on anthropological and social demography). 
Blum Alain. 2002. Resistance to identity categorization in France.

the following observations: faced with increasing violence in the transport sector, RATP adopted a mediation policy aimed at communicating with, or reaching out to the perpetrators of violent acts through intermediaries who are close to them. These intermediaries, referred to as "big brothers" and "agents of social prevention and mediation," are recruited in neighbourhoods populated largely by immigrants. From the start, the "big brother" initiative was conceived by RATP in explicitly ethnic terms, since a large number of the young "trouble-makers" are of immigrant background (from Sub-Saharan Africa and the Maghreb). Given this profile, it was decided to recruit young men of similar immigrant stock, who might be perceived as authority figures by troubled youths from cultures where elder brothers are indeed viewed in this way (Wieviorka, 1999).

The second policy is connected to national education, which is faced with both problems of academic difficulties, and problems of violence in schools. The creation of the Priority Educational Zones (ZEP) and the Sensitive Zones, which define geographic sectors where the educational establishments wield substantially enhanced financial resources and enjoy the services of a larger number of personnel, does not seem to have been handled, for the most part, from an ethnic angle. Although there is a connection between these zones and those sectors heavily populated by immigrants, the negotiating points that were developed from the local level all the way up to the national are tied, first and foremost, to difficulties associated with resources and support, rather than to mechanical criteria related to the proportion of this or that population in a particular area. The educational zone policy employs a spatial approach based on social analysis

\section{1}

In: Kertzer David, Arel Dominique (dir.), Census and identity : the politics of race, ethnicity, and language in national censuses. Cambridge, Cambridge University Press, p. 121-147. (New Perspectives on anthropological and social demography). 
Blum Alain. 2002. Resistance to identity categorization in France.

and practice, rather than one which categorizes the population on the basis of origins. Wieviorka's work on violence explains how ethnic criteria were used to formulate a policy to combat violence in urban transportation settings. Interestingly, however, there is no discussion of such criteria in the discussion of the problem of violence in schools. The descriptions of school incidents sent to the authorities refer only to the social background of the students involved, not to their ethnic origins.

This does not mean that the criteria employed in granting ZEP status take no account at all of the characteristics of the population, or of the schools under review. The enquiries that are made to establish the statistical criteria needed in considering whether to grant ZEP status take social composition (the PCS) and nationality into consideration, on the basis of files put together by students' parents. In addition, the perception of these special educational zones is rather strongly linked to an ethnic vision, a vision of what could be "the two priorities — the two urgent tasks of the ZEP policy (and of the network of priority schools): social and ethnic mixing, and the quality of human resources and staff' (G. Chauveau and R. Chauveau 1995; G. Chauveau, 1999). This approach, favoured by Chauveau, shows clearly what is at stake in a differential policy which is aware of the relationship between immigration and academic failure.

That being said, it is undoubtedly the case that the decision to grant ZEP arises from a negotiation process. Moreover, it is a political decision that takes into account the balance of power between rectorates, teachers, unions, and ministries. Negotiations are thus highly exclusive, and are based on interactions between local collectivities and the central administration, rather than on the establishment of precise criteria. Such criteria are used more after the fact, so to

212

In: Kertzer David, Arel Dominique (dir.), Census and identity : the politics of race, ethnicity, and language in national censuses. Cambridge, Cambridge University Press, p. 121-147. (New Perspectives on anthropological and social demography). 
Blum Alain. 2002. Resistance to identity categorization in France.

speak, when analyzing the importance of sectors, and not so much during the negotiation phase.

Tensions and grievances, such as those expressed in 1998 in the department Seine-St-Denis, result in prompt negotiations and in the granting of ZEP status independent of predefined criteria.

\section{Conclusion}

The debate discussed in this article was spawned by the publication of one particular survey. Its relevance, however, goes beyond this survey. As it evolved, the debate unmasked the underlying tensions that exist in the complex relationship between the issue of representing a society in ethnic terms and social science in France.

The complexity of the debate stems, in part, from its link to polemics that have affected French society since the mid-nineteenth century. These polemics juxtaposed a republican ethic with national affirmation, the latter term being understood very much from an East-Central European perspective. The current debate often refers to the older arguments, which sometimes obscures the fact that the discussion has since undergone a profound transformation.

The transformation can be seen at various levels of the debate: By integrating advances in social science in the use of statistics, the current debate distinguishes, albeit not always quite clearly, between the construction of a statistical category on the one hand, and an understanding of particular phenomena, such as segregation, or racism, on the other. By virtue of its universal and formative nature, the statistical category is constructed not simply for the purposes of analysis, but has strong institutional links. The construction and naming of statistical categories are not a neutral

213

In: Kertzer David, Arel Dominique (dir.), Census and identity : the politics of race, ethnicity, and language in national censuses. Cambridge, Cambridge University Press, p. 121-147. (New Perspectives on anthropological and social demography). 
Blum Alain. 2002. Resistance to identity categorization in France.

exercise. Furthermore, these categories freeze situations that are in motion, or in flux, by attaching individuals to a single affiliation, thus making it difficult to understand the phenomenon of multiple identity.

The use of statistics as a "universal" tool in the formulation of policy is also at issue. If the fight against discrimination in the workplace and in the housing sector rests on a careful study of variables of an overtly ethnic type, it is far from certain that a simplified and very incomplete approach, based on a "recording" of ethnicity, is the direction to take. In addition, the absence of this tradition in France has led researchers to attempt to define such categories without taking account of how individuals define themselves. This makes the exercise even more artificial.

Above all, there is no absolute in the representation of identity, and a social science approach cannot deduce the universal character of certain concepts and expressions from particular experiences. Moreover, one cannot ignore the various influences affecting the construction of categories, from social and institutional imperatives, to public activity and political pressures. The existence of numerous alternative approaches to the study of the ethnicization process suggests that a return to the analytical framework developed in the nineteenth century would obscure the complexity of identity. There is certainly a political demand for an understanding of ethnicity, but this need not necessarily translate into the formulation and use of statistical categories. The goal should rather be to develop multiple forms of analyses, at different levels, which will not bind the individual exclusively or perpetually to a particular ethnic group.

\section{4}

In: Kertzer David, Arel Dominique (dir.), Census and identity : the politics of race, ethnicity, and language in national censuses. Cambridge, Cambridge University Press, p. 121-147. (New Perspectives on anthropological and social demography). 
Blum Alain. 2002. Resistance to identity categorization in France.

There is no doubt that the strong pressure on INSEE or other public institutions to take ethnicity into account could lead to a change in current practice. However, the diversity of opinion makes the introduction of census variables of a North American type doubtful. Many arguments support this observation. It is important to bear in mind that the fight against discrimination currently underway is often linked to a firm opposition to identifying individuals through categories that could be used to ascribe identity based on ethnicity. On the other hand, in the absence of a long-standing perception of these types of categories, it appears that it is practically impossible to propose categories expressing a generally accepted identity. We can, therefore, assume that, even if political and social pressure is strong, the responses will be numerous and complex. It is unlikely that they will converge towards any generally accepted categorization scheme, such as would appear on a French census.

\footnotetext{
${ }^{1}$ When dealing with important social questions, the tendency in France is to set up an independent structure which serves as intermediary between society and the body politic: the High Commission on Population and the Family, Ethics Committee, the High Commission on Integration, as well as the National Committee on Computers and Freedom, the National Committee on Statistical Information, etc. . The composition of these structures is supposed to reflect a balance between representatives of various social groups. They are politically “neutral” spaces, designed for confrontation and negotiation between social partners (unions are often represented in these bodies), judicial authorities (members of the State Council, etc.), and researchers. ${ }^{2}$ The influence of Michel Foucault on more general categories connected to public activity is apparent, even though it is not always explicitly acknowledged.

${ }^{3}$ For an analysis of the debates that took place in the 1850s-70s, particularly during the International Statistical Congresses of 1857 and 1872, see Labbe 1997.
}

215

In: Kertzer David, Arel Dominique (dir.), Census and identity : the politics of race, ethnicity, and language in national censuses. Cambridge, Cambridge University Press, p. 121-147. (New Perspectives on anthropological and social demography). 
Blum Alain. 2002. Resistance to identity categorization in France.

${ }^{4}$ Contrary to the usage in Eastern Europe, where "nationality“ referred to an ethnocultural affiliation within a larger civic affiliation, "nationality” in France specifically referred to a civic affiliation. For example, a French resident from Germany without French citizenship was categorized as someone of "German nationality,“ and thus as a “foreigner.” A Breton-speaking French citizen, however, was categorized as someone of French nationality, with no official category available to express a Breton cultural identity. In Austria, by contrast, a Czech-speaker of Bohemia was categorized as both of Czech nationality and of Austrian citizenship, since “nationality” was officially considered to be a different concept than “citizenship.” ${ }^{5}$ See http://census.ined.fr, a website that reproduces most the French census forms.

${ }^{6}$ The Overseas French territories have two different administrative status : they are either Départements (DOM : Départements d'Outre-Mer), or Territoires (TOM : Territoires d'Outre-Mer). The first ones have the same administrative status as all the other Départements. Territoires have a more autonomous status.

${ }^{7}$ The author of this work was even sued by his institution, which chose to respond to his assertions through legal action in July 1998. The press thus began to pay greater attention to the debate. Hervé Le Bras has been accused of defaming his institute. The complaint was withdrawn in April 1999 by a new director of INED. The roots of this episode, which are discussed more fully below, lie with Hervé Le Bras’ political analysis of relations between the extreme right and demography.

${ }^{8}$ The debate, “Démographie et catégories ethniques,” is archived ar http://census.ined.fr.

${ }^{9}$ The italicized terms are taken from a report by Jean Michel Belorgey, “Lutter contre les discriminations,” prepared for Martine Aubry, Ministry of Employment and Solidarity.

216

In: Kertzer David, Arel Dominique (dir.), Census and identity : the politics of race, ethnicity, and language in national censuses. Cambridge, Cambridge University Press, p. 121-147. (New Perspectives on anthropological and social demography). 


\section{List of References}

Alonso, William and Starr, Paul (eds.) 1987, The Politics of Numbers, New York: Sage.

Anderson, Benedict 1991, Imagined Communities, London: Verso.

Anderson, Margo J. 1988, The American Census, A Social History, New Haven: Yale University Press.

Bernard, Philippe 1999, 'Un rapport préconise une 'autorité indépendante' contre les discriminations,” Le Monde (7 April): 10.

Bertaux, Sandrine 1997, “Le concept démographique d’assimilation: un label scientifique pour le discours sur l’intégration?” Revue française des affaires sociales, 2: 37-52.

Blum, Alain 1994, Vivre, naître et mourir en URSS, Paris: Plon.

Blum, Alain 1998, “Comment décrire les immigrés? A propos de quelques recherches sur l'immigration,” Population 3: 569-88.

Blum, Alain and Gouseff, Catherine 1997, 'Les nationalités dans les recensements russes et soviétiques,” in Jean-Louis Rallu, Youssef Courbage, and Victor Pichè (eds.), Anciennes et nouvelles minorités, Paris: INED/London: John Libbey, pp. 49-72.

Blum, Alain, Desrosières, Alain, Gouseff, Catherine, and Magaud, Jacques (eds.) 1998, “Compter l'autre,” Histoire \& Mesure 13. (Thematic issue)

Boltanski, Luc 1982, Les cadres, la formation d'un groupe social, Paris: Editions de Minuit.

Brubaker, Rogers 1992, Citizenship and Nationhood in France and Germany, Cambridge, MA: Harvard University Press. 
Blum Alain. 2002. Resistance to identity categorization in France.

Chauveau, Gérard et Rogovas Chauveau, 1995, A l'école des banlieues, Paris: ESF.

Chauveau, Gérar 1999, “Les ZEP, effets pervers de l'action positive,” Plein droit 41-42: 56-59.

Courgeau, Daniel and Lelièvre, Eva 1996, “Changement de paradigme en démographie,” Population 3 : 645-54.

Decouflé, André-Clément 1997, “L’intégration: quelques idées simples,” Revue française des affaires sociales 2: 29-36.

De la Gorce, Gilles 1991, 'L’individu et la sociologie--soixante ans d'étude de la mobilité sociale,” Revue de synthèse 2:237-63.

Desrosières, Alain 1993, La politique des grands nombres, Histoire de la raison statistique, Paris: La Découverte.

Desrosières, Alain and Thévenot, Laurent 1988, Les catégories socioprofessionnelles, Paris: La Découverte.

Dupâquier, Jacques 1997, “Les chiffres de l’immigration: mythes et réalités,” Revue des sciences morales et politiques 1: 71-99.

Gousseff, Catherine 1997, ‘L’élaboration des catégories nationales dans les recensements: décalages entre législation et outils de mesure,” Revue française des affaires sociales 2: 53-70.

Gribaudi, Maurizi 1998, "Penser la diversité comme processus,” 14 November, Available at http://census.ined.fr.

218

In: Kertzer David, Arel Dominique (dir.), Census and identity : the politics of race, ethnicity, and language in national censuses. Cambridge, Cambridge University Press, p. 121-147. (New Perspectives on anthropological and social demography). 
Blum Alain. 2002. Resistance to identity categorization in France.

Héran, François 1998, “Ethnique ta statistique?” in “Statistique sans conscience n'est que ruine...” Actes du colloque, Paris: CGT/CFDT INSEE, pp. 28-35.

Hirsch, Francine 1997, "The Soviet Union as a Work-in-Progress: Ethnographers and the Category Nationality in the 1926, 1937, and 1939 Censuses,” Slavic Review 56: 251-78.

Houle, René 1997, "Russes et non Russes dans la direction des institutions politiques et économiques en URSS, Une étude des recensements, 1926-1979,” Cahiers du Monde russe 38: 347-66.

INED 1993, Vingt-deuxième rapport sur la situation démographique de la France, Paris.

INSEE 1998, “Droit de réponse du directeur de l'INSEE à Jacques Dupâquier,” Revue des sciences morales et politiques 2:131-38.

Jenkins, Alan 1999, “See No Evil,” The Nation (28 June): 15-19.

Kateb, Kamel 1998a, 'La gestion statistique des population dans l'empire colonial français, Le cas de l’Algérie, 1830-1960,” Histoire \& Mesure 13: 77-112.

Kateb, Kamel 1998b, Histoire statistique des populations algériennes pendant la colonisation française (1830-1962), PhD Dissertation, École des Hautes Études en Sciences Sociales, Paris.

Labbé, Morgane 1997, “Le projet d’une statistique des nationalités discuté dans les sessions du Congrès International de Statistique (1853-1876),” in Francis Ronsin, Hervé Le Bras and

In: Kertzer David, Arel Dominique (dir.), Census and identity : the politics of race, ethnicity, and language in national censuses. Cambridge, Cambridge University Press, p. 121-147. (New Perspectives on anthropological and social demography). 
Blum Alain. 2002. Resistance to identity categorization in France.

Elisabeth Zucker-Rouvillois (eds.), Démographie et Politique, Dijon: Editions Universitaires de

Dijon, pp. 127-42.

Lacroix, Janine et Suzane Thave 1997, “Les immigrés dans les recensements: décalages entre législation et outils de mesure,” Revue française des affaires sociales 2: 71-100.

Le Bras, Hervé 1981, “L’histoire secrète de la fécondité,” Le Débat 8: 76-101.

Le Bras, Hervé 1991, Marianne et les lapins - l’obsession démographiques, Paris: Olivier Orban.

Le Bras, Hervé 1994, Le sol et le sang, Paris: Editions de l’Aube.

Le Bras, Hervé 1998a, Le Démon des origines, Démographie et extrême-droite, Paris: Editions de l'Aube.

Le Bras, Hervé 1998b, “Les Français de souche existent-ils?”, Quaderni 22: 36.

Lepetit, Bernard 1995, Les formes de l'expérience: Une autre histoire sociale, Paris: Albin Michel.

Mauco, Georges 1932, Les étrangers en France, Leur rôle dans l'activité économique, Paris: Armand Colin.

Muñoz-Pérez, Francisco and Tribalat, Michèle 1984, "Mariages d'étrangers et mariages mixtes en France,” Population 3: 427-62.

220

In: Kertzer David, Arel Dominique (dir.), Census and identity : the politics of race, ethnicity, and language in national censuses. Cambridge, Cambridge University Press, p. 121-147. (New Perspectives on anthropological and social demography). 
Blum Alain. 2002. Resistance to identity categorization in France.

Noiriel, Gérard 1988, Le creuset français: Histoire de l'immigration, XIX-XXème siècle, Paris: Seuil, Translated as The French Melting Pot, Immigration, Citizenship, and National Identity, Minneapolis: University of Minnesota Press, 1996.

Noiriel, Gérard 1991, La tyrannie du national: Le droit d'asile en Europe, 1793-1993. Paris: Calmann-Lévy.

Rallu, Jean-Louis 1998, “Les catégories statistiques utilisées dans les Dom-Tom depuis le début de la présence française,” Population 3: 589-608.

Rémond, René 1996, Le "fichier juif», Rapport de la commission présidée par René Rémond au Premier ministre, Paris: Plon.

Revue française des affaires sociales 1997, "Insertion, intégration: concepts et pratiques," Special issue.

Richard, Jean-Luc 1999, Dynamiques démographiques et socio-économiques de l'intégration des jeunes générations d'origine immigrée en France, Etude à caractère longitudinal (19751990) réalisée à partir de l'échantillon démographique permanent, $\mathrm{PhD}$, Institut d’Etudes Politiques, Paris.

Richard, Jean-Luc 1999, “Qu’est-ce qu’un Français?” Les dossiers de Pour la Science (French edition of Scientific American) 24:22-27.

Sauvy, Alfred 1954, Théorie générale de la population, Tome II: Biologie sociale, Paris: Presses Universitaires de France.

221

In: Kertzer David, Arel Dominique (dir.), Census and identity : the politics of race, ethnicity, and language in national censuses. Cambridge, Cambridge University Press, p. 121-147. (New Perspectives on anthropological and social demography). 
Blum Alain. 2002. Resistance to identity categorization in France.

Simon, Patrick 1993a, “Chronique de l'immigration,” Population 1: 125-81.

Simon, Patrick 1993b, “Nommer pour agir,” Le Monde, 28 April.

Simon, Patrick 1997, "La statistique des origines--“race” et ethnicité dans les recensements aux Etats-Unis, Canada et Grande Bretagne,” Sociétés Contemporaines 26:11-44.

Simon, Patrick 1998, "Nationalité et origine dans la statistique française: Les catégories ambiguës,” Population 3: 541-68.

Simon, Patrick and Tapia, Claude 1998 Le Belleville des Juifs tunisiens, Paris: Autrement 104,

"Statistique des différences ethnographiques de la population d'un État, comprenant leur influence sur le bien-être, les mœurs et la civilisation de la nation),” in E. Engel (eds.), Compte rendu général des travaux du Congrès international de statistique dans ses séances tenues à Bruxelles, 1852, Paris, 1855, Vienne, 1857 et Londres, 1860, Berlin and St-Petersburg, 1863, p. 156.

Szreter, Simon 1996, Fertility, class and gender in Britain, 1860-1940, Cambridge, UK: Cambridge University Press.

Todd, Emmanuel 1994, Le destin des immigrés: Assimilation et ségrégation dans les démocraties occidentals, Paris: Seuil.

Tribalat, Michèle 1989,“Immigrés, étrangers, Français: l’imbroglio statistique,” Population \& sociétés No. 241:1-4.

222

In: Kertzer David, Arel Dominique (dir.), Census and identity : the politics of race, ethnicity, and language in national censuses. Cambridge, Cambridge University Press, p. 121-147. (New Perspectives on anthropological and social demography). 
Blum Alain. 2002. Resistance to identity categorization in France.

Tribalat, Michèle, (eds.) 1991, Cent ans d'immigration, Étrangers d'hier, Français

d'aujourd'hui, Travaux et documents, 131, Paris: INED/Presses Universitaires de France.

Tribalat, Michèle 1995a, Faire France, Paris: La découverte.

Tribalat, Michèle 1995b, “Censure à l'INSEE,”L'Histoire No. 193: 39.

Tripier, Maryse 1999, “De l'usage de statistiques 'ethniques'," Hommes et migrations, 1219:27-32.

Wieviorka, Michel 1999, Violence en France, Paris: Seuil.

A large bibliography of article published about this polemic is available on http://census.ined.fr.

In: Kertzer David, Arel Dominique (dir.), Census and identity : the politics of race, ethnicity, and language in national censuses. Cambridge, Cambridge University Press, p. 121-147. (New Perspectives on anthropological and social demography). 